\title{
AN EVALUATION OF MACRONUTRIENT NUTRITIONAL STATUS OF SUGAR BEETS IN CRITICAL STAGES OF GROWTH IN RESPONSE TO FOLIAR APPLICATION OF MULTI-MICRONUTRIENT FERTILIZERS
}

\author{
Witold Grzebisz, Katrzyna Przygocka-Cyna, \\ Remigiusz Lukowiak, Maria Biber \\ Department of Agricultural Chemistry and Environmental Biogeochemistry \\ University of Life Sciences in Poznan
}

\begin{abstract}
The actual yields of sugar beets harvested by farmers in Poland are much below the yielding potential of currently cultivated varieties, even when grown on fertile soils. Deficiency of micronutrients can be considered as a factor which prohibits reaching a state of nutrient balance, especially in nitrogen, by a crop. The aim of the study was to assess the effect of foliar application of multi-microelement fertilizers on a sugar beet nutritional status in early stages of canopy growth and, in turn, on yields of taproots and recoverable sugar. For this purpose, in two growing seasons, 2005 and 2006, eight field trials were set up in the region of Wielkopolska on fertile soils originated from sandy loam. A simple experimental design comprised three treatments: (1) control (a plot fertilized only with NPK), and (2) multi-microelement fertilizer composed of cations (Mi), (3) cations plus boron (MiB). It has been found that the applied micronutrient fertilizers had a significant effect, irrespectively of the field location and seasonal yield variability, on the sugar beet nutritional status, especially in terms of nitrogen. Yields of taproots have increased by $31.6 \%$ and $22.1 \%$ for the $\mathrm{NPK}+\mathrm{Mi}$ and $\mathrm{NPK}+\mathrm{MiB}$ treatments, respectively. Almost the same degree of increase was noted for yields of recoverable sugar. The achieved nitrogen balance at the stage of harvestable part development, as measured at $\mathrm{BBCH} 43$, was probably the main reason for high positive response of sugar beet crop to external supply of micronutrients. All the analyzed standards of sugar beet nutritional status, DRIS indices, responded to the investigated experimental factor, i.e., foliar application of multi-microelement fertilizer, but only
\end{abstract}

Witold Grzebisz, Department of Agricultural Chemistry and Environmental Biogeochemistry, University of Life Sciences, Wojska Polskiego Street 71F, 60-625 Poznań, e-mail: witegr@up.poznan.pl 
those for nitrogen underwent a change from negative to positive values, thus enabling us to make a reliable yield prognosis.

Key words: sugar beet, macronutrient content, critical stages of growth, DRIS indices, multi-microelement fertilizers.

\title{
OCENA STANU ODŻYWIENIA BURAKÓW CUKROWYCH W KRYTYCZNYCH FAZACH ROZWOJU W REAKCJI NA DOLISTNE NAWOŻENIE WIELOSKŁADNIKOWYMI NAWOZAMI MIKROELEMENTOWYMI
}

\begin{abstract}
Abstrakt
Plony buraków cukrowych zbierane przez rolników w Polsce kształtują się na poziomie dużo niższym, nawet na glebach żyznych, niż plony potencjalne obecnie uprawianych odmian. Niedobór mikroelementów może być rozważany jako jeden z czynników, który uniemożliwia uzyskanie przez rośliny stanu równowagi żywieniowej, zwłaszcza w przypadku azotu. Celem badań była ocena wpływu dolistnie stosowanych wieloskładnikowych nawozów mikroelementowych na stan odżywienia roślin we wczesnych fazach rozwoju buraków, i w konsekwencji na plony korzeni i cukru. Cel zweryfikowano w latach 2005 i 2006 , zakładając w Wielkopolsce 8 doświadczeń zlokalizowanych na żyznych glebach, wytworzonych $\mathrm{z}$ polodowcowych glin moreny dennej. Prosty schemat doświadczenia zawierał 3 kombinacje: (1) kontrolę (obiekt nawożony NPK) oraz 2 obiekty z dolistnie stosowanymi nawozami mikroelementowymi wieloskładnikowymi zawierające w swym składzie (2) kationy, (Mi), (3) kationy i bor (MiB). Stwierdzono, niezależnie od lokalizacji doświadczenia i zmienności sezonowej plonów, istotne działanie nawozów mikroelementowych na stan odżywienia roślin, zwłaszcza azotu. Plony korzeni zwiększyły się o $31.6 \%$ i $22.1 \%$, odpowiednio w przypadku wariantu Mi i MiB. Analogiczną reakcję odnotowano dla plonów cukru. Główną przyczyną dodatniej reakcji buraków cukrowych na dolistną aplikację nawozów mikroelementowych było uzyskanie przez rośliny w fazie BBCH43 zbilansowanego stanu odżywienia roślin azotem. Analizowane normy odżywienia roślin, indeksy DRIS, wykazały reakcję na badany czynnik doświadczalny, czyli nawozy mikroelementowe wieloskładnikowe, lecz tylko w przypadku azotu nastapiła zmian wartości indeksów z ujemnych na dodatnie, umożliwiając tym samym wiarygodną prognozę plonów.
\end{abstract}

Słowa kluczowe: buraki cukrowe, makroelementy, krytyczne fazy rozwoju, indeksy DRIS, wieloskładnikowe nawozy mikroelementowe.

\section{INTRODUCTION}

Yielding potential of modern sugar beet varieties, i.e. their attainable yields under predominant conditions in Poland, is relatively high. The potential yield of taproots as presented annually in the COBORU reports is at the level of $70 \mathrm{t} \mathrm{ha}^{-1}$ (COBORU 2009). The country annual averages however are much lower, ranging in the last decade from 39 (2000) to 51 (2007) t $\mathrm{ha}^{-1}$ (GUS, 2001 2009). The annual yield gap, i.e. unharvested part of attainable yield, ranges therefore from $27 \%$ to $45 \%$. The main reason for high production risk and concomitant year-to-year yield variability is a low level of soil fertility, in turn increasing sensitivity of this crop to unfavorable meteorological conditions (GRzEBISz et al. 2005). 
Modern, high yielding sugar beet varieties are highly sensitive to supply of nutrients, including both a high rate of early canopy growth and the final quality of storage roots. In temperate regions of the world, the fast early growth of sugar beet seedlings is crucial for efficient solar energy absorption by developing plant canopy (BoIfFIN et al. 1992). In the course of the growing season, sugar beet crop reaches $85 \%$ of the canopy cover, as the target soil surface cover area, when its leaf area index (LAI) is ca 3.0 (ANDRIEU et al. 1997). It has been documented that this level of LAI corresponds to $120 \mathrm{~kg} \mathrm{~N}^{-1}$ taken up by the expanding sugar beet canopy (MALNOU et al. 2006). The main target of growers is therefore to create growing conditions in a way allowing a crop to take this amount of nitrogen as quickly as possible, as a prerequisite of the highest efficiency of solar energy absorption.

The Diagnosis and Recommendation Integrated System (DRIS) concept is widely applied to evaluate the plant nutritional status of crop plants. The DRIS nutritional concept is based on a comparison of nutrient ratios of currently cultivated crop with optimum ratios developed for a high-yielding group-population (DRIS norms) (WALWORTH, Sumner 1987). In this study, it has been assumed that by means of the DRIS method it can be possible to identify the most limiting or the most sensitive nutrient to the applied measures.

The objectives of the conducted study were (i) to qualitatively evaluate sugar beet crop canopy nutritional status at early stages of growth (ii) to determine yields of taproots and recoverable sugar in response to foliar application of multi-microelement fertilizers.

\section{MATERIALS AND METHODS}

Field experiments were conducted in 2005 and 2006 years on four sugar beet productive fields localized in Central-Western Poland. Soils in the experimental sites are loamy sands lying on sandy loam, classified, according to Polish standards, as a very good rye complex, belonging to the agronomy class IVa. Agrochemical soil characteristics of the experimental plots were determined each year at the beginning of the growing season, i.e. at early stage of sugar beets growth, BBCH16. The main agrochemical soil characteristics are as follows: 1) soil $\mathrm{pH}$ : site-to-site variable, predominantly acid to slightly acid; 2) content of available nutrients: phosphorus - low; potassium - high; magnesium - high and very high.

The single-factorial experiment with sugar beet consisted of tree treatments as presented below:

1. NPK (acronym NPK);

2. NPK + multi-microelement fertilizer $(\mathrm{NPK}+\mathrm{Mi})$; 
3. $\mathrm{NPK}+$ multi-microelement fertilizer and boron $(\mathrm{NPK}+\mathrm{MiB})$.

All treatments were replicated three times in a simple block design. Each year cereals (winter wheat or spring barley) were a preceding crop for sugar beet. Farmyard manure was applied in three of four sites. In the fourth one white mustard was grown and plowed down in autumn as a green manure. Phosphorus and potassium rates were adjusted to the soil test and applied in the previous autumn (1/XI). Nitrogen application rate was established by means of the $\mathrm{N}_{\min }$ method in order to reach at the $16^{\text {th }}$ leaf stage $\mathrm{N}$ mineral total content of $200 \mathrm{~kg} \mathrm{ha}^{-1}$ in the soil zone of $0.0-0.9 \mathrm{~m}$. It has been assumed that this level of mineral $\mathrm{N}$ is sufficient to harvest 50-55 $\mathrm{t}$ $\mathrm{ha}^{-1}$ of taproots. Herbicides and all other agro-technologies followed standard practices.

Multi-microelement fertilizers were prepared at concentrations of $70 \mathrm{Cu}$, $400 \mathrm{Fe}, 170 \mathrm{Mn}, 20 \mathrm{Mo}, 150 \mathrm{Zn} \mathrm{mg} \mathrm{dm}{ }^{-3}$ in the chelated by EDTA for the Mi formulation and plus $105 \mathrm{~g} \mathrm{dm}^{-3}$ of $\mathrm{B}$ in the form of boron-ethanolamine for the MiB formulation. Both fertilizers were applied on sugar beet foliage at three consecutive stages of plant growth: $16^{\text {th }}, 26^{\text {th }}$ and $43^{\text {rd }}$, according to the $\mathrm{BBCH}$ scale at a rate of $3 \mathrm{dm}^{3} \mathrm{ha}^{-1}$ for each spraying. Yield of taproots was assessed from an area of $10,8 \mathrm{~m}^{2}$. Yield of recoverable sugar was determined by means of the Venema analytical procedure in the Środa Sugar Beet Factory (Pfeifer \& Langen Polska).

For the purpose of the study, 10 plants were sampled at three consecutive stages of wheat growth according to the $\mathrm{BBCH}$ scale: 16 (before the first foliar spray), 43 (after the second but before the third foliar spray), 49 (at technological plant maturity). At each sampling date the harvested plant samples were partitioning into subsamples of leaves and taproots and then dried $\left(65^{\circ} \mathrm{C}\right)$. Nitrogen content of the plant tissues was determined by using the Kjeldahl method (Kjeltec Auto Distillation). Phosphorus was determined calorimetrically (Analitykjena Specord 40) whereas $\mathrm{K}, \mathrm{Mg}, \mathrm{Mn}$ and $\mathrm{Cu}$ by the FAAS method (Flame Atomic Absorption Spectrophotometer, Varian 250 plus). The results are expressed on a dry matter (DM) basis.

The data from experiments were elaborated by using analyses of variance for each year separately and for interaction year and treatments, using computer programs Statistica 7. For F-test showing significant differences, Tukey's test (HSD) at the probability level $\alpha=0.05$ was additionally performed to compare mean values (LSD). Linear and non-linear regression fittings were determined on mean values (of four replications), by using statistical software Statistica 7. The goodness of fit was evaluated by $R^{2}$ values.

Evaluation of the sugar beet nutritional status at growth stages BBCH16 and 43 has been conducted by means of two approaches. The first one relies on comparison of average values for each of the studied nutrient with concomitant sets of standard sufficiency ranges, according to BARŁóG (2009). The second method applied during the study was Diagnosis and Recommendation Integrated System (Dris, Walworth, Sumner 1987), which provides 
a means of linking leaf nutrient concentrations to the yield of the tested crops. This method requires two sets of data, classically elaborated via dividing the total tested population into two parts, i.e., high and low yielding. Each of these sets of data comprises averaged data on nutrient ratios for each studied pair of nutrients, for example for nitrogen $(\mathrm{N})$ and phosphorus (P) expressed as N/P for the low-yielding population and as $\mathrm{n} / \mathrm{p}$ for the standard yielding population. In the calculation practice applied in this study the tested set of data was considered as the low population, but the concomitant set for high-yielding norms, i.e., $\mathrm{n} / \mathrm{p}$ and their coefficient of variation (CV) are as a rule taken from literature (BARŁÓG 2009, personal communication) Table 1 . In the present study, leaf samples were analyzed for $\mathrm{N}, \mathrm{P}, \mathrm{K}, \mathrm{Ca}$ and $\mathrm{Mg}$. In the second step of procedure, for each of the tested pairs specific nutrient ratios $\mathrm{f}(\mathrm{N} / \mathrm{P})$ were calculated. Based on each function, an index for

Table 1

Diagnosis and Recommendation Integrated System (DRIS) norms from the high yielding subpopulation of sugar beets grown in the central-western part of Poland (BARŁóG 2009)

\begin{tabular}{|c|c|c|c|c|}
\hline \multirow{2}{*}{ Nutrient ratio } & \multicolumn{4}{|c|}{ Discriminators } \\
\cline { 2 - 5 } & yield of taproots, $n=113$ & \multicolumn{2}{c|}{ yied of recoverable sugar, $n=144$} \\
\cline { 2 - 5 } & average & $\mathrm{CV}(\%)$ & average & CV (\%) \\
\hline $\mathrm{N} / \mathrm{P}$ & 10.32 & 27.07 & 10.38 & 23.47 \\
\hline $\mathrm{N} / \mathrm{K}$ & 0.933 & 18.18 & 0.946 & 20.39 \\
\hline $\mathrm{N} / \mathrm{Mg}$ & 10.80 & 49,38 & 10.86 & 33.84 \\
\hline $\mathrm{N} / \mathrm{Ca}$ & 6.591 & 42.52 & 7.116 & 50.49 \\
\hline $\mathrm{K} / \mathrm{P}$ & 11.44 & 32,29 & 11.40 & 30.18 \\
\hline $\mathrm{K} / \mathrm{Ca}$ & 7.077 & 37.47 & 7.429 & 38.54 \\
\hline $\mathrm{K} / \mathrm{Mg}$ & 11.70 & 47.05 & 11.73 & 34.05 \\
\hline $\mathrm{Ca} / \mathrm{P}$ & 1.924 & 65.48 & 1.846 & 64.68 \\
\hline $\mathrm{Ca} / \mathrm{Mg}$ & 1.853 & 59.29 & 1.811 & 53.80 \\
\hline $\mathrm{Mg} / \mathrm{P}$ & 1.159 & 52.80 & 1.068 & 43.00 \\
\hline
\end{tabular}

each nutrient was computed separately, accordingly to respective functions and equations. The choice of appropriate functions depends for example on $\mathrm{N} / \mathrm{P}$ and $\mathrm{n} / \mathrm{p}$ values, as presented below:

$$
\begin{array}{lll}
\text { when } \mathrm{N} / \mathrm{P}>\mathrm{n} / \mathrm{p} & \text { then } & f(\mathrm{~N} / \mathrm{P})=\left[\frac{\mathrm{N} / \mathrm{P}}{\mathrm{n} / \mathrm{p}}-1\right] \cdot \frac{1000}{\mathrm{CV}} \\
\text { when } \mathrm{N} / \mathrm{P}<\mathrm{n} / \mathrm{p} & \text { then } & f(\mathrm{~N} / \mathrm{P})=1-\left[\frac{\mathrm{n} / \mathrm{p}}{\mathrm{N} / \mathrm{P}}\right] \cdot \frac{1000}{\mathrm{CV}}
\end{array}
$$


where:

$\mathrm{N} / \mathrm{P}$ - nutrient ratio of $\mathrm{N}$ to $\mathrm{P}$ content in the analysed crop,

$\mathrm{n} / \mathrm{p}$ - nutrient ratio of $\mathrm{N}$ to $\mathrm{P}$ in the DRIS normative ratio,

$\mathrm{CV}$ - coefficient of variation for $\mathrm{n} / \mathrm{p}$ ratio for the DRIS norm,

1000 - coefficient of recalculation

$$
\begin{aligned}
\mathrm{I}(\mathrm{N}) & =\frac{f(\mathrm{~N} / \mathrm{P})+f(\mathrm{~N} / \mathrm{K}-f(\mathrm{Mg} / \mathrm{N}-f(\mathrm{Ca} / \mathrm{N})}{4} \\
\mathrm{I}(\mathrm{P}) & =\frac{f(\mathrm{P} / \mathrm{Mg})-f(\mathrm{~N} / \mathrm{P}-f(\mathrm{~K} / \mathrm{P}-f(\mathrm{Ca} / \mathrm{P})}{4} \\
\mathrm{I}(\mathrm{K}) & =\frac{f(\mathrm{~K} / \mathrm{P})-f(\mathrm{~N} / \mathrm{K}-f(\mathrm{Ca} / \mathrm{K}-f(\mathrm{Mg} / \mathrm{K})}{4} \\
\mathrm{I}(\mathrm{Ca}) & =\frac{f(\mathrm{Ca} / \mathrm{N})+f(\mathrm{Ca} / \mathrm{P}+f(\mathrm{Ca} / \mathrm{K}-f(\mathrm{Mg} / \mathrm{Ca})}{4} \\
\mathrm{I}(\mathrm{Mg}) & =\frac{f(\mathrm{Mg} / \mathrm{N})+f(\mathrm{Mg} / \mathrm{K}-f(\mathrm{P} / \mathrm{Mg}+f(\mathrm{Mg} / \mathrm{Ca})}{4}
\end{aligned}
$$

\section{RESULTS AND DISCUSSION}

The main objective of the study was to assess the effect of two multimicroelement fertilizers, first containing all basic cations (Mi) and the second one enriched with boron $(\mathrm{MiB})$ on sugar beet crop nutritional status and in turn on yields of taproots and recoverable sugar. The main hypothesis of the conducted study was that any yield increase could be achieved provided that plants were able to reach the point of balanced nutrients supply, but nitrogen-oriented. Taking into account the main target of sugar beet growers, i.e. end-effect of new production measures, yields of taproots (TR) and recoverable sugar (RS) were assessed first. The site-to-site variability of yield of taproots for the NPK treatment, considered as the control, as documented by a coefficient of variation, was low, i.e. less than $10 \%$, and therefore not significant. It was found, however, that the tested multi-microelement fertilizers significantly affected yields of taproots (Figure 1). In comparison to the NPK treatment, yields increased $31.6 \%$ and $22.1 \%$ in the $\mathrm{NPK}+\mathrm{Mi}$ and $\mathrm{NPK}+\mathrm{MiB}$ treatments, respectively. On average, sugar beet crop fertilized with NPK+Mi yielded $70 \mathrm{t} \mathrm{ha}^{-1}$. This volume of harvested yield is equal to the level of attainable yields in Poland during the years of study (COBORU 2009). Plants fertilized with NPK+MiB yielded $c a 5 \mathrm{t} \mathrm{ha}^{-1}$ 


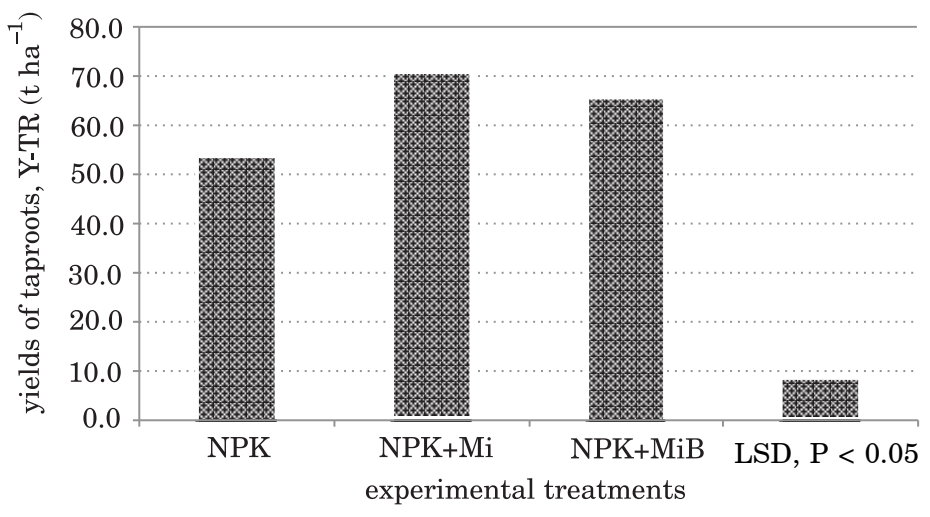

Fig. 1. Yield of sugar beet taproots in response to foliar application of multimicronutrient fertilizers

lower as compared to the NPK+Mi treatment, but significantly higher than in the NPK control. A slightly lower yield increase following additional boron supplementation seems unexpected and can be only explained by means of two hypothesis: i) lower boron uptake by plants due to insoluble borate complexes precipitated in the spraying container, ii) lower uptake of divalent cations such as calcium and magnesium by plants. On the other hand, the yields obtained clearly emphasize the yield-forming role of an external supply of micronutrient factors.

The same pattern of the influence produced by both multi-microelement fertilizers on sugar beet crop appeared in the yield of recoverable sugar (Figure 2). The relative yield increase was $31.3 \%$ and $23.7 \%$ for the NPK+Mi

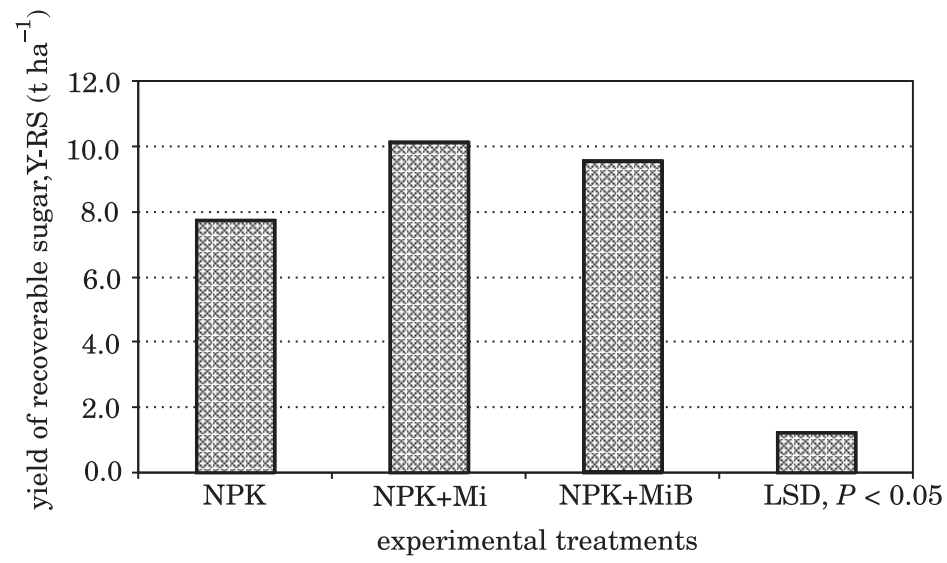

Fig. 2. Yield of recoverable sugar in response to foliar application of multimicronutrient fertilizers 
and $\mathrm{NPK}+\mathrm{MiB}$ fertilizers, respectively. For this end product. the effect of added boron was less limiting that for the yield of taproots. The main reason of a slightly lower yield gap was $0.7 \%$ higher content of sugar (data not shown but available from the authors).

The second objective of the study was to explain the yields increments by means of evaluating the sugar beet plants nutritional status over the course of the growing season, with special attention paid to the early stages of sugar beet development. According to DuRR et al. (1992), the pattern of individual rate of growth of sugar beet seedlings is established at the stage of $4^{\text {th }}$ leaf, provided sufficient supply of nutrients and water. However, as presented in Table 2, at this sugar beet growth stage favorable growth conditions are rare. In order to verify this hypothesis during the course of sugar beet growing seasons, plants were sampled three times. The first sampling was done when plants reached the stage of $6^{\text {th }}$ leaf (BBCH16). This stage of sugar beet development of canopy should reflect the plant nutritional status just before the first multi-microelement fertilizer application on plant foliage. The sugar beet plant nutritional status evaluation was conducted by BARŁóG (2009), based on critical ranges worked out for the centralwestern part of Poland. In 2005, the content of all studied macronutrients in leaves was within their own specific critical ranges. However, the averages for nitrogen, phosphorus and potassium were the lower while those for magnesium and calcium were the medium values of their critical ranges. All values, except for magnesium, were much below the nutrient specific optimum. In 2006, the sameobservations were made, except for nitrogen. Its average content was below the threshold range, but without any nega-

Table 2

Content of macronutrients in sugar beet leaves, stage of growth - BBCH16 (g kg-1 DM)

\begin{tabular}{|c|c|c|c|c|c|}
\hline \multirow{2}{*}{$\begin{array}{c}\text { Statistical } \\
\text { parameters }\end{array}$} & \multicolumn{5}{|c|}{ Nutrients } \\
\hline & $\mathrm{N}$ & $\mathrm{P}$ & K & $\mathrm{Ca}$ & $\mathrm{Mg}$ \\
\hline $\begin{array}{l}\text { Critical } \\
\text { ranges* }\end{array}$ & $36.0-54.5$ & $2.2-8.1$ & $41.0-86.0$ & $5.8-15.5$ & $2.6-7.7$ \\
\hline Optimum & 45.7 & 5.2 & 65.0 & 10.6 & 5.1 \\
\hline \multicolumn{6}{|c|}{2005} \\
\hline Mean & 36.58 & 3.975 & 43.05 & 8.500 & 5.900 \\
\hline $\mathrm{SD}$ & \pm 7.702 & \pm 0.206 & \pm 3.755 & \pm 3.160 & \pm 0.896 \\
\hline $\mathrm{CV}, \%$ & 21.1 & 5.1 & 8.7 & 31.2 & 15.9 \\
\hline \multicolumn{6}{|c|}{2006} \\
\hline Mean & 30.60 & 3.600 & 42.93 & 9.200 & 5.375 \\
\hline $\mathrm{SD}$ & \pm 2.15 & \pm 0.24 & \pm 3.60 & \pm 1.0 & \pm 0.50 \\
\hline $\mathrm{CV}, \%$ & 7.0 & 6.8 & 8.4 & 10.8 & 9.5 \\
\hline
\end{tabular}

*BARŁóG (2009) 
tive impact on the final yield of taproots (Table 2). The assessment of sugar beet plant nutritional status at this stage of sugar beet growth does not give us any knowledge on the current plant nutritional status, but seems to be a very useful indicator of the general growth conditions. At that period of sugar beet growth, the main target of growers is to make the last correction of plant nutritional status in order to reach, as quickly as possible, the targeted 85\% canopy cover, required for efficient solar energy absorption, as a prerequisite of high final yield (MALNOU et al. 2006).

Table 3

Content of macronutrients in sugar beet leaves, stage of growth - BBCH43 $\left(\mathrm{g} \mathrm{kg}^{-1}\right)$

\begin{tabular}{|c|c|c|c|c|c|c|}
\hline \multirow{2}{*}{ Treatment } & \multirow{2}{*}{$\begin{array}{c}\text { Level } \\
\text { of treatment }\end{array}$} & \multicolumn{5}{|c|}{ Nutrients } \\
\hline & & $\mathrm{N}$ & $\mathrm{P}$ & $\mathrm{K}$ & $\mathrm{Ca}$ & $\mathrm{Mg}$ \\
\hline Critical* $^{*}$ & $\begin{array}{c}\text { ranges } \\
\text { optimum }\end{array}$ & $\begin{array}{c}34.7-45.3 \\
40.0\end{array}$ & $\begin{array}{c}2.7-4.8 \\
3.6\end{array}$ & $\begin{array}{c}35.7-62.5 \\
49.1\end{array}$ & $\begin{array}{c}3.1-7.7 \\
5.2\end{array}$ & $\begin{array}{c}2.3-5.8 \\
3.8\end{array}$ \\
\hline \multirow{3}{*}{ Fertilizers $(F)$} & NPK & 40.39 & 3.038 & 35.13 & 11.00 & 5.075 \\
\hline & $\mathrm{NPK}+\mathrm{Mi}$ & 44.18 & 3.113 & 36.71 & 11.98 & 5.400 \\
\hline & $\mathrm{NPK}+\mathrm{MiB}$ & 43.04 & 3.113 & 37.16 & 11.14 & 5.188 \\
\hline \multicolumn{2}{|l|}{$\mathrm{LSD}, P \leq 0.05$} & 0.30 & - & - & - & - \\
\hline \multirow{2}{*}{ Year $(Y)$} & 2005 & 41.83 & 3.083 & 36.18 & 11.81 & 5.292 \\
\hline & 2006 & 43.23 & 3.092 & 36.49 & 10.92 & 5.150 \\
\hline \multicolumn{2}{|l|}{$\mathrm{LSD}, P \leq 0.05$} & - & - & - & - & - \\
\hline \multicolumn{2}{|c|}{$\mathrm{LSD}, P \leq 0.05 F x Y$} & - & $x$ & - & - & - \\
\hline
\end{tabular}

*BARŁÓG (2009)

$x$ - significant interaction

Two of the three foliar sprayings of the multi-microelement fertilizers, conducted during the course of the growing season, took place before the classical stage of sugar beet nutritional status assessment, i.e., development of harvestable part (BBCH43). The average content of the tested elements in fully developed leaves showed some specific differences in nutrients i) in comparison to the previous stage, ii) in response to the applied fertilizers. In comparison to BBCH16 stage, a marketable increase was noted for nitrogen and calcium, while all the other nutirents decreased (Table 3).

Our comparison of the data for the NPK treatment to the nutrient specific threshold optima and ranges clearly indicate a low nutritional status for phosphorus and potassium and excess calcium. The average content of nitrogen in young but fully developed leaves was optimum, but that of potassium was below the lower threshold limit. Having determined such low $\mathrm{K}$ values, one should expect it would have a predominant effect on final yields of taproots and/or recoverable sugar. But, as presented in Figures 1 
and 2, sugar beet crops did not respond negatively to such temporary $\mathrm{K}$ deficiency and or the low $\mathrm{P}$ content. Among the analysed nutrients, it was only phosphorus that showed significant response to the year and fertilizer interaction. This interaction was significant due to the differences found in the NPK plot. In the second year, plants fertilized with NPK contained significantly less phosphorus. The other treatments revealed completely opposite albeit not significant relations. The plant growth and yields was unaffected even by the excess of calcium.

Among all the studied nutrients, it was only the nitrogen content that showed a significant response to the multi-microelement fertilizers applied to sugar beet plant foliage. However, some positive trends were also observed for other nutrients, although they were nutrient specific.

Sugar beet growth stage BBCH43 is considered classical for plant nutritional status evaluation. However, the critical ranges did not enable us to make any ranks of the nutrients with respect to the sugar beet nutritional status. For this purpose, the DRIS concept of plant crop nutritional status can be applied (BARŁóg 2009, Walworth, Sumner 1987). The main task of this procedure is to assess plant nutritional imbalance (Table 4). The applied

Table 4

Sugar beet nutritional status at BBCH43 as assessed by means of the DRIS indices

\begin{tabular}{|c|c|c|c|c|c|c|}
\hline \multirow{2}{*}{ Plant indicator } & \multirow{2}{*}{$\begin{array}{c}\text { Experimental } \\
\text { treatments }\end{array}$} & \multicolumn{5}{|c|}{ DRIS indices (I) } \\
\hline & & $\mathrm{N}$ & $\mathrm{P}$ & $\mathrm{K}$ & $\mathrm{Ca}$ & $\mathrm{Mg}$ \\
\hline \multirow{3}{*}{ Yield of taproots } & NPK & -0.623 & -8.218 & -14.89 & 16.88 & 6.856 \\
\hline & $\mathrm{NPK}+\mathrm{Mi}$ & 1.203 & -9.888 & -16.30 & 18.00 & 6.980 \\
\hline & $\mathrm{NPK}+\mathrm{MiB}$ & 0.780 & $-8,845$ & -13.82 & 15.58 & 6.302 \\
\hline \multirow{3}{*}{$\begin{array}{c}\text { Yield of recoverable } \\
\text { sugar }\end{array}$} & NPK & -1.713 & -10.10 & -16.22 & 17.88 & 10.16 \\
\hline & $\mathrm{NPK}+\mathrm{Mi}$ & 0.218 & -12.01 & -17.60 & 19.06 & 10.33 \\
\hline & $\mathrm{NPK}+\mathrm{MiB}$ & -0.172 & $-10,81$ & -14.99 & 16.61 & 9.354 \\
\hline
\end{tabular}

DRIS procedure was conducted taking into account two end products, i.e. yield of taproots (Y-TR) and yield of recoverable sugar (Y-RS), considered as plant specific indicators. For the yield of taproots, irrespective of the experimental treatment, the following order of nutrients was found:

$$
\mathrm{K}>\mathrm{P}>\mathrm{N}>\mathrm{Mg}>\mathrm{Ca}
$$

This order clearly demonstrates that potassium was the most limiting nutrient, followed by phosphorus, both presenting negative values of DRIS indices, which simply means that both nutrients were highly unbalanced. It is frequently presented in literature that a DRIS index exceeding an absolute value of \pm 15 indicates an acute plant nutritional disorder. In this study, this is the case of potassium, whose absolute values exceeded -15 in the 
$\mathrm{NPK}+\mathrm{Mi}$ treatment with respect to the yield of taproots and for both treatments with respect to the yield of recoverable sugar. The same but opposite in sign was found for calcium, i.e. $>+15$ for both yield indicators. Hence, a regression model of DRIS indices for calcium was developed as a function of the potassium index, as presented below:

$$
\mathrm{I}(\mathrm{Ca})=-0.9138 \mathrm{I}(\mathrm{K})+3.0466 \text { for } R^{2}=0.988 \text { and } n=6 \text { for } P \leq 0.001
$$

However, the variability of both indices due to application of the multimicroelement fertilizers to sugar beet foliage did not significantly affect either the yield of taproots or the yield of recoverable sugar.

Considering the experiment's objectives, nitrogen showed the most interesting response of DRIS indices to the applied fertilizer. The presented indices are of crucial importance for explaining the sugar beet yield response to the applied multi-microelement fertilizers. At first, the nitrogen indices were the lowest, indicating a state of smooth balance. Later, the nitrogen indices underwent a big change in response to the applied fertilizers, from negative for the NPK fertilized crop to positive for treatments receiving the micronutrient fertilizers. The degree of the change as described by DRIS indices for nitrogen, (I)N, enabled us to make a reliable prognosis of the yield of taproots (Y-TR). The regression equation clearly indicates that under a balanced $\mathrm{N}$ status the harvested yield of taproots can reach $c a 60 \mathrm{t} \mathrm{ha}^{-1}$ :

$$
\mathrm{Y}-\mathrm{TR}=9.110 \mathrm{I}(\mathrm{N})+59.33 \quad \text { for } R^{2}=0.994 \text { and } P \leq 0.001
$$

Quite an opposite change in DRIS indices was observed for phosphorus, $\mathrm{I}(\mathrm{P})$. The fertilizers increased the state of imbalance of phosphorus, although a reliable and significant prognosis of taproots yield was still possible:

$$
\mathrm{Y} \text {-TR }=-9.664 \mathrm{I}(\mathrm{P})-23.36 \quad \text { for } R^{2}=0.872 \text { and } P \leq 0.05
$$

DRIS indices were also developed, but using another set of standards, i.e. for yield of recoverable sugar. In this case, the order of DRIS indices is the same as found for the yield of taproots. Again, the lowest imbalance was calculated for nitrogen, but negative values were noted both for the NPK and NPK+MiB treatments. The fertilizers significantly decreased the DRIS indices for $\mathrm{N}$, but it was only for the NPK $+\mathrm{Mi}$ treatment that a change from negative to positive values occurred. The relationship between DRIS indices for nitrogen and phosphorus and yields of recoverable sugar were significant, which made it possible to suggest a reasonable yield prognosis. It is derived from from equation No. 4, where under conditions of $\mathrm{N}$ internal balance, the harvested sugar yield can reach ca $10 \mathrm{t} \mathrm{ha}^{-1}$ :

$$
\begin{array}{ll}
\mathrm{Y}-\mathrm{RS}=1.236 \mathrm{I}(\mathrm{N})+9.840 & \text { for } R^{2}=0.998 \text { and } P<0.001 \\
\mathrm{Y}-\mathrm{RS}=1.187(\mathrm{P})-3.868 & \text { for } R^{2}=0.823 \text { and } P<0.05
\end{array}
$$

The data on the nutrient content in sugar beet canopy at BBCH43 fully demonstrates the importance of nitrogen balance as a key element for making any sound assessment of canopy nutritional status as a prerequisite for 
any reliable prognosis of yield of taproots and recoverable sugar. These data corroborate the thesis that nitrogen in well-balanced sugar beet canopy can be taken as the main plant nutrient responsible for both the rate of dry mater accumulation by growing crop canopy and its division among main organs (leaves and roots) (RUBIO et al. 2003, WEBB et al. 1997).

Table 5

\begin{tabular}{|c|c|c|c|c|c|c|}
\hline \multirow{2}{*}{ Treatment } & \multirow{2}{*}{$\begin{array}{c}\text { Level } \\
\text { of treatment }\end{array}$} & \multicolumn{5}{|c|}{ Nutrients } \\
\hline & & $\mathrm{N}$ & $\mathrm{P}$ & $\mathrm{K}$ & $\mathrm{Ca}$ & $\mathrm{Mg}$ \\
\hline \multirow{3}{*}{ Fertilizers $(F)$} & NPK & 37.06 & 3.013 & 31.70 & 5.638 & 4.800 \\
\hline & $\mathrm{NPK}+\mathrm{Mi}$ & 36.44 & 3.100 & 35.40 & 6.338 & 4.800 \\
\hline & $\mathrm{NPK}+\mathrm{MiB}$ & 37.68 & 3.188 & 35.69 & 5.250 & 4.512 \\
\hline \multicolumn{2}{|l|}{$\mathrm{LSD}, P \leq 0.05$} & - & - & - & 0.060 & - \\
\hline \multirow{2}{*}{$\operatorname{Year}(Y)$} & 2005 & 39.87 & 3.058 & 35.53 & 5.750 & 4.717 \\
\hline & 2006 & 34.25 & 3.142 & 33.00 & 5.733 & 4.692 \\
\hline \multicolumn{2}{|l|}{$\mathrm{LSD}, P \leq 0.05$} & 0.33 & - & - & - & \\
\hline \multicolumn{2}{|c|}{$\mathrm{LSD}, P \leq 0.05 ; F x Y$} & - & - & - & - & $x$ \\
\hline
\end{tabular}

$x$ - significant interaction

The third plant sampling was conducted at sugar beet harvest, related to the stage of BBCH49. Compared to the previous sampling dates, the nutrient content was evaluated both in leaves and in taproots. In comparison to the stage of $\mathrm{BBCH} 43$, the content of nutrients in leaves tended to be much lower. It was only the calcium content that showed a significant response to the applied multi-microelement fertilizers. A significant increase was noticed for the $\mathrm{NPK}+\mathrm{Mi}$ treatment, in contrast to the NPK+MiB treatment, in which the Ca concetration fell. Nitrogen content at this stage of sugar beet growth showed only seasonal variability, being much lower in 2006. Among the five analysed macronutrients, magnesium alone was sensitive to the interaction of fertilizer and season. The main reason for the significant response was a rise in the $\mathrm{Mg}$ content in the first year in response to the Mi fertilizer application. This variability can be used to forecast yields. However, it appeared that a statistically accurate prognosis can be made only for recoverable sugar yield:

Y-RS $=37.30 \mathrm{Mg}-10.32 r=0.71$ for $n=6$ and $P \leq 0.05$

where:

Y-RS - yield of recoverable sugar, $\mathrm{t} \mathrm{ha} \mathrm{h}^{-1}$;

$\mathrm{Mg}$ - magnesium content in leaves at BBCH49, $\mathrm{g} \mathrm{kg}^{-1} \mathrm{DM}$. 
Generally, the content of nutrients in taproots is not used to make any assessment of plant nutritional status. Nonetheless, in our experiment, it enabled us to assess the effect of the tested fertilizers on the content of macronutrients (Table 6). With respect to the effect of the multi-microelement fertilizers, significant response was observed only for calcium. The same pattern of its content was found in leaves. Identical but non-siginificant trends were observed for magnesium. Opposite ones appeared for potassium. The potassium content in taproots showed a significant response to

Table 6

Content of macronutrients in sugar beet taproots at BBCH49 ( $\left.\mathrm{g} \mathrm{kg}^{-1} \mathrm{DM}\right)$

\begin{tabular}{|c|c|c|c|c|c|c|}
\hline \multirow{2}{*}{ Treatment } & \multirow{2}{*}{$\begin{array}{c}\text { Level } \\
\text { of treatment }\end{array}$} & \multicolumn{5}{|c|}{ Nutrients } \\
\hline & & $\mathrm{N}$ & $\mathrm{P}$ & $\mathrm{K}$ & $\mathrm{Ca}$ & $\mathrm{Mg}$ \\
\hline \multirow{3}{*}{ Fertilizers $(F)$} & NPK & 10.51 & 1.339 & 10.33 & 0.888 & 1.300 \\
\hline & $\mathrm{NPK}+\mathrm{Mi}$ & 9.375 & 1.513 & 9.900 & 1.150 & 1.488 \\
\hline & $\mathrm{NPK}+\mathrm{MiB}$ & 9.325 & 1.788 & 1.089 & 0.838 & 1.300 \\
\hline \multicolumn{2}{|l|}{$\mathrm{LSD}, P \leq 0.05$} & - & - & - & 0.02 & - \\
\hline \multirow{2}{*}{ Year $(Y)$} & 2005 & 1.094 & 1.558 & 10.30 & 0.925 & 1.383 \\
\hline & 2006 & 8.533 & 1.533 & 10.44 & 0.992 & 1.342 \\
\hline \multicolumn{2}{|l|}{$\mathrm{LSD}, P \leq 0.05$} & 0.13 & - & - & - & - \\
\hline \multicolumn{2}{|c|}{$\mathrm{LSD}, P \leq 0.05 ; F x Y$} & $x$ & - & $x$ & - & - \\
\hline
\end{tabular}

$x$ - significant interaction

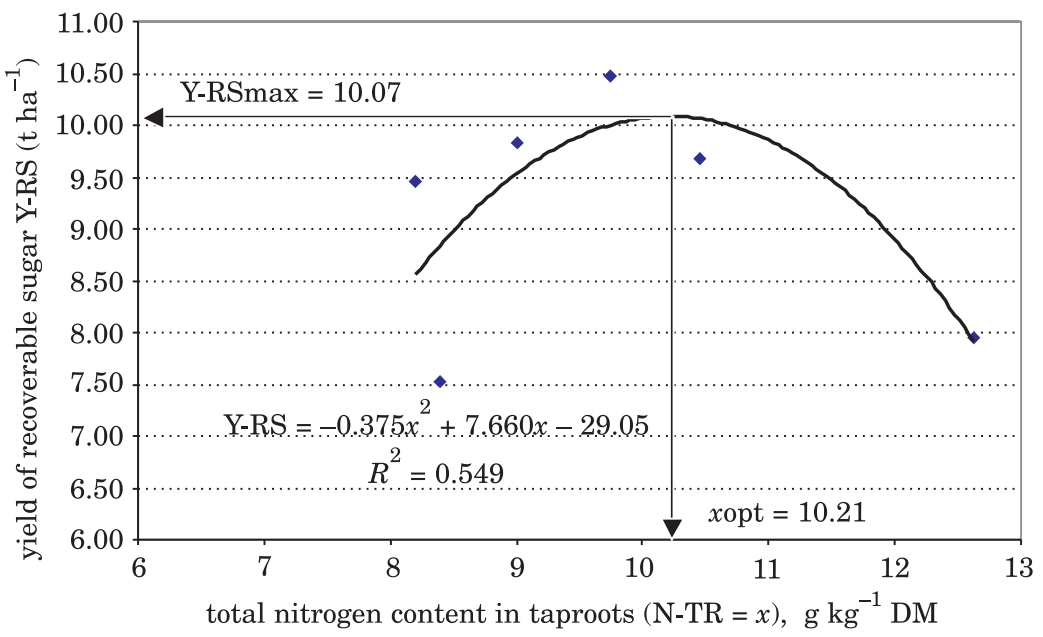

Fig. 3. Yield of recoverable sugar as a function of nitrogen content in taproots at BBCH49 
the fertilizer and year interaction, but the results in both years were contrary. In the first year, a significant decrease in the $K$ content in response to the multi-microelement fertilizer application was found. In the second year, the response consisted of a significant increase. The nitrogen content, despite the lack of significant responses, showed a decreasing tendecy, correlatedx to the tested fertilizer and year interaction. The regression of the total $\mathrm{N}$ content $\left(\mathrm{TN}_{\mathrm{TR}}\right)$ in taproots against the harvested yield of recoverable sugar (Y-RS) allowed us to calculate an optimum of $\mathrm{N}$ content and also to make a reliable prognosis of recoverable sugar yield (Figure 3). In can be concluded that the total nitrogen content in tissues of taproot up to $c a 10 \mathrm{~g}$ $\mathrm{kg} \mathrm{DM}$ is a prerequisite of a recoverable sugar yield increase.

\section{CONCLUSIONS}

1. Sugar beet crops, irrespectively of location and year-to-year variability, showed significant

response to the application of multi-microelement fertilizers, as demonstrated by increased yields of taproots and recoverable sugar.

2. Nitrogen DRIS index can be applied as a very useful measure of sugar beet nutritional status at the beginning of harvestable plant part development.

3. The evaluated sugar beet nutritional status and yield increases indicate an insufficient supply of micronutrients to sugar beet plants during the critical stages of growth.

4. Sugar beet has high tolerance to an internal balance of cations provided that their supply is sufficient to control nitrogen, i.e. to lower nitrogen internal imbalance.

\section{REFERENCES}

Andrieu B., Allirand J., JaGGard K. 1997. Ground cover and leaf area index of maize and sugar beet crop. Agronomie, 17: 315-321.

BARŁóg P. 2009. Studia nad żywieniem buraka cukrowego ze szczególnym uwzględnieniem sodu [Studies on nutrition of sugar beet with particular attention paid to sodium]. Nawozy i Nawożenie, 35: 147 s. (in Polish)

Boiffin J., Durr C., Fleury A., Marin-laflache A., Maillet I. 1992. Analysis of the variability of sugar beet (Beta vulgaris L.) growth during the early stages. I. Influence of various conditions on crop establishment. Agronomie, 12: 515-525.

COBORU 2009. PDO experiments, report 2009 (in Polish).

Durr C., Boiffin J., Fleury A., Coulomb I. 1992. Analysis of the variability of sugar beet (Beta vulgaris L.) growth during the early stages. I. Factors influencing seedling size in field conditions. Agronomie, 12: 527-535. 
Grzebisz W., BarŁog P., Szczepaniak W. 2005. The efficient strategy of sugar beet fertilization with potassium - Part I. Scientific background. Listy Cukrovarnicke a Reparske, 121 (4): $126-129$

Malnou C., Jaggard K., Sparkes D. 2006. Nitrogen fertilizer and the efficiency of the sugar beet crop in later summer. Europ. J. Agron. 28: 47-56.

Rubio G., Zhu J., Lynch J. 2003: A critical test of the prevailing theories of plant response to nutrient availability. Am. J. Bot., 90(1): 143-152.

Statistical Yearbook 2001, 2008. GUS, Warszawa 2001, 2008.

Webi C., Werker A., Gilligan C. 1997. Modeling the dynamical components of the sugar beet crop. Ann. Bot., 80: 427-436.

WeKker A., JAGGARD K. 1998. Dependence of sugar beet yield on light interception and evapotranspiration. Agric. Forest Meteorol., 89: 229-240.

Walworth J., Sumner N. 1987. The Diagnosis and Recommendation Integrated System (DRIS). Adv. Soil Sci., 6: 149-188. 
